\title{
The Ethics of Wasatinyah and the Pursuit of Gender Equality
}

\author{
Etin Anwar
}

\begin{abstract}
The paper deals with the concept of wasatiyah (moderation) as an ethical framework for community making and its impact on the pursuit of gender equality. Qur'an 2:143 speaks about the correlation between making a fair community (al-ummah al-wasat) and piety, which is inclusive of both men and women. As both terms are intertwined, any efforts to discuss wasatizyah must include how Muslims relate to God and how this relationship is exercised in all areas of their lives. Given that this intersection is a matter of ethics, my paper will demonstrate that wasatīyah affords the inclusion of both genders as ethical agents in the pursuit of a fair community.

I first discuss how the ethics of wasatizyah provide a framework for community building by drawing some parallels between Prophet Muhammad's creation of a fair and inclusive community and how Muslims could embody God's message within themselves and their communities. I then show how including women in the community-making process echoes both the Islamic ethics of moderation and the value of women as ethical agents.
\end{abstract}

Etin Anwar is associate professor of religious studies (Hobart and William Smith Colleges, Geneva, NY) and author of Gender and Self in Islam (Routledge: 2006). She has published several articles on Ibn Sina, Meister Eckhart, Ibn Arabi, anti-Americanism, and women's movements; contributed to the Encyclopedia of Islam and the Muslim World; and was featured in the XXI TV documentary "Muslim Women in Our Midst: The Path to Understanding" in conjunction with "America at the Crossroads" (2006). In addition, she is a co-founder of One-on-One Friendship, a network for youth that promotes friendship with conscience for social justice, cultural exchange, and creative collaboration. 


\section{Introduction}

This paper deals with the concept of wasatīyah as an ethical framework for community making and its impact on the pursuit of gender equality. Such scholars as Mohd Shukri Hanapi, Raymond Willian Baker, and Mohammad Hashim Kamali translate wasatiyah as "moderation." Hanapi highlights the concept's epistemological contexts and its application to diversity promotion in contemporary Malaysia, ${ }^{1}$ whereas Baker examines its current use and compatibility with democracy. The latter envisions how the "abstract consensus of the Islamic mainstream [wasatizyah] [could be transformed] into a viable plank of a practical party," like the Wasat Party, which exercises people's voices for good governance through democratic means. ${ }^{2}$ Along the same line, Kamali situates wasatīyah within the legal framework and notes its promising role in striking "the middle ground between idealism and reality and between traditional and modern society." 3

My work is built on the premise of wasatityah ethics as a foundational paradigm for equitable gender relationships in community-building efforts. I show how making a fair and inclusive community (ummah wasat) assumes individual piety and each person's role as a moral agent in society. For instance, Q. 2:143 speaks of the correlation between erecting such a community and the Muslims' piety. The term ummah is mentioned nineteen times in fifteen chapters, whereas wasat and its variations are mentioned only four times. The term ummah wasat portrays a community in which people's values and pious practices seek to promote the public good and social justice. As this communal effort and individual piety are intertwined, any discussion of the ethics of wasativyah must include how Muslims relate to God and to each other, as well as how these relationships are exercised in all areas of their lives. This particular form of ethics echoes the Qur'an's role as "guidance for humanity" (huda li al-nās) that provides its adherents with a meaningful life on both the personal and the communal levels (Q. 2:185).

The term wasatīyah is prevalent because scholars use it to reveal Islam's relevance to addressing such contemporary social issues as democracy, interfaith dialogue, religious violence, and gender equality. ${ }^{4}$ Its deployment challenges Muslims to be on their best behavior, both individually and communally, and urges them to address those social, cultural, sexual, and political problems that afflict their societies in terms of moderation by making sure that their virtuous character accords with Islam's perception of moral agency. For Muslims, moral agency comes from God and the Qur'an, as revealed to and implemented by the Prophet. Embodying this divine message is, therefore, a matter of ethics. 
The goal of this paper is to contextualize why the concept of wasativyah as an ethical framework matters and how it provides a path toward gender equality. I first discuss how the functionality of wasatiyah ethics correlates with the Prophet's pursuit of ethical formation and his effort to build a Muslim community. I then examine the implication of the ethics of wasatiyah in the pursuit of gender equality and the challenges Muslim women face in promoting a fair and inclusive community.

\section{The Ethics of Wasațyah and Making a Just Community}

Muslims have continuously renewed and recovered the pristine Islamic teachings and sought God's affirmation in all worldly affairs. Among these efforts is the deployment of wasatizyah to address modern challenges, which shows the relevance between what the Qur'an says about a just and inclusive community and how Muslims embody justice and diversity in response to their ever-changing communities and contemporary problems. While their efforts to embody Islam vary due to differences in geopolitical contexts, all of them have one thing in common: Islam serves as an ethical paradigm that outlines human beings' rights, duties, roles, and rules in terms of its adherents' relationships with God, fellow human beings, and nature.

Here Islam, as an ethical system, consists of the sum of values that capture what God revealed to humanity, what the Prophet exemplified, and what human reason perceives as a life of perfection in accordance with the Qur'an and Hadith. The sum of revelation and reason provides a way to attain perfection in this life. The Prophet provides the best example of including both reason and revelation, an approach that enabled him to discover the best model for building a fair and just community. In this section I discuss wasatizyah as the foundation of an ethical framework by drawing some parallels between his efforts to produce an inclusive community and how Muslims can embody God's message within themselves and their communities.

Seeking a life of perfection is a common theme in Islamic ethics. In Islamic philosophy, the subject of Islamic ethics has traditionally been closely related to what Plato and Aristotle have theorized. They introduced the notion of a perfect moral outlook and how to achieve it. Greek philosophy later on shaped the development of Islamic ethics when philosophers such as al-Farabi (d. 950), Ibn Sina (d. 1037), Ibn Bājjah (d. 1185), and Ibn Rushd (d. 1198) integrated Greek thought into Islamic civilization. ${ }^{5}$ Although Islamic ethics during the time of medieval Europe shared its themes (e.g., what constitutes the good life and happiness) with Greek thought, it remained Islamic in its foundational sense: It explains how human beings can relate to God, fellow human 
beings, and nature in a way that is compatible with both reason and revelation. Morality for Muslims, therefore, falls in both the religious and the ethical domain.

The ground for religious and moral lifestyles comes from the Qur'an and Hadith, both of which provide a model of moderation in life. The concept of wasatityah as an ethical value is drawn from Q. 2:143. ${ }^{6}$ Defining wasat provides a hint of what is expected from Muslims in seeking a meaningful life. Ibn Arabi (d. 1240) asserts that wasat is linguistically equivalent to khiyār (chosen, selected) and 'adl (just). ${ }^{7}$ Others, among them al-Mawardi (d. 1058), defines it in three senses: (1) selected, as in the case of someone with an elevated (central) position in society; (2) moderation in everything as being moderate in religion; and (3) justice, which is seen as the mean between excess and lack. ${ }^{8}$ The accepted meanings for wasat vary from "the chosen, the best, being fair, humble, moderate, istiqämah (persistent), observant of Islam, not extreme to either end in matters pertaining worldly or the after-life, spiritual or corporeal but should be balanced between the two ends." ${ }^{9}$ Regardless of how this concept is defined, it highlights the importance of Muslims' responsibility to cultivate good character, create a just and inclusive community, and exercise their religiosity with others to help achieve the public good.

The ethics of wasatiyah suggests God's immanent role and how Muslims fulfill their responsibility of embodying His attributes, such as justice and being a mercy to the worlds, in multiple personal religious and social settings. Qur'an 2:143 demands that they respond to God's call to bear witness to the Prophet's ethical message and project it through proper conduct. The occasions of revelation (asbāb al-nuzūl) of Q. 2:143, which deals with the community's change of the prayer direction from Jerusalem to the Ka'bah, ${ }^{10}$ reflects God's decision that the early Muslims needed a fresh start in order to reorient their faith, rituals, and political alliances.

During their first sixteen months in Madinah, Muslims prayed toward Jerusalem. The Prophet and his followers, all of whom valued Islam's connection to Abraham's heritage and place of origin, hoped that such a connection would garner the Jewish community's theological, political, and social acceptance. However, political tensions overshadowed the potential political and social alliances. The new prayer direction did not reflect Islam's desire that Muslims distanc themselves from Judaism or even hate Jews; rather, it taught them to invent a new practice that would enable the community to orient itself toward the greater good, resolve the politics of communal tension peacefully, and continue to retain the best-existing practices. The Qur'an labels such a community a fair and chosen one. 
The new prayer direction reaffirmed how building a fair and chosen community involved the inclusion the best-existing practices as exemplified by the Prophet, for the Ka'bah had a sanctuary for locals and non-Makkan visitors from various racial and religious backgrounds for centuries. He later adopted this structure as the locus for pilgrimage due to its prophetic importance and connection with Judaism. After all, the Jewish prophets Abraham and Ishmael had erected it (Q. 2:127). Indeed, the core belief in God has a Jewish tone, lineage, and practice. Here, the principle of wasatityah at its core functions as a way to reconcile differences and come to a meeting point where various forces converge in a positive way, so that personal biases in the name of religion do not cloud our reflection and discretion.

As indicated earlier, the Prophet's life provides the best example of how to be cognizant of multiple realities in a given society and how to adopt the best of them. He created and led a fair, inclusive community at a time when justice was nonexistent. His first effort was to lay his community's foundation on the revolution of a person's heart, a heart that is cognizant of God, ${ }^{11}$ by making the pre-Islamic concept of Alläh the convergent point (wasat). Toshihiko Izutsu points to the convergence of geographical, theological, ethical, and epistemological impacts in regard to this particular concept. Pre-Islamic pagan, Jewish and Christian Arabs, and pagan monotheistic Arabs all used Allāh in their own unique ways. ${ }^{12}$ The pagan Arabs used it to refer to the Creator of the Heavens and Earth (Q. 29:61), the Giver of Rain (Q. 29:63), the Helper (Q. 31:31), the Grantor of Safety (Q. 29:65), and the Lord of the Ka'bah. Jewish and Christian Arabs used Allāh to denote their Biblical God.

Although these Jewish and Christian concepts were foreign to the pagan Arabs, such a concept had been incorporated into Bedouin cultures. The processional chanting when approaching and circumambulating the Ka'bah provided an example of how prevalent the role of Allāh was in pre-Islamic Arabia ${ }^{13}$ : "Here I am, O Allāh, here I am. You have no partner, except such a partner as you have. You possess him and all that is his." Such chanting reaffirms Allāh's role as the convergence between paganism and monotheism. This assimilation process happened due to Judaism and Christianity's influential presence in the Arabian Peninsula. ${ }^{14}$ The Christian influences on the concepts of prophecy, God, and revelation were also notable. The peninsula was located between the Byzantine Empire and the Persian Empire's vassal states (e.g., al-Hirah) that were dominated by the Monophysite and Nestorian churches. Those who wrote the Prophet's biography recorded that he met Bahirah, the Christian monk who foresaw his prophethood, and Waraqah ibn Nawfal, who confirmed it. ${ }^{15}$ 
The Prophet's efforts to understand and embody God's message, as well as to later on teach the concept of tawhìd (divine unity) to Muslims and nonMuslims, demonstrate a process of community making. A fair community is inclusive of best practices and promotes the greater good. The convergence of best practices produces a middle ground or a meeting point in which other values and practices can manifest themselves. When confronted with the Jewish community's rejection and political conspiracy, the Prophet neither forbade them to oppose him nor urged his community to conquer Jerusalem. Rather, he turned his face toward heaven (Q. 2:144) and prayed that the prayer direction would be changed to the Ka'bah built by Abraham and Ishmael. In addition, he was well aware of the "monotheistic current of ancient Arab religion," known as haniff. ${ }^{16}$ Qur'an 10:105 confirms that he ought to direct his face toward this hanif religion and never be one of the ungrateful (käfirūn). Mohsin Khan translates hanäfah as "Islamic monotheism, i.e. to worship none but Allah alone." ${ }^{17}$ As the concept of Allāh serves as a common thread among the diverse beliefs of the peninsula's inhabitants, it functions as a meeting point of best practices in regards to the notion of God. The inclusion of best practices is, therefore, key to the formation of a fair and inclusive community.

The various communities' references to Allāh in the pre-Islamic peninsula and its later use by the Prophet show that this particular concept is unifying, a fact that allows it to become a middle ground or the converging point for what is moral for Muslims in terms of establishing a fair community. The Prophet promoted this unifying inclusive framework known to everyone even to women (e.g., Khadijah). He explained his path to God in terms of three concepts of Allāh, and yet made them specific enough for Muslims to make it unique: "No god is there but one God" (Q. 5:73), "God is but one god" (Q. 4:171), and "Your god is one god, so submit to him" (Q. 22:34). ${ }^{18}$ When he speaks about God, he has in mind the Abrahamic paths of monotheism as stated in Q. 6:161: "Say, indeed, as for me has guided me my Lord to a straight path - a right religion - the religion of Abraham, a pure monotheist, and he was not from the polytheists." By referring to Abraham's monotheism, the Prophet brings forth a new concept of Allāh to which each group can relate.

In creating a fair, inclusive community, the Prophet continued the chain of prophecy linking Abraham, Ishmael, Isaac, Jacob, Moses, and Jesus (Q. $2: 136)$ by connecting his prophetic mission with this chain. Like Islam's other prophets, his universal message centered on tawhìd and yet his mission was particular to his time and place. The Qur'an justifies the universal prophecy 
by proclaiming that "[e]very nation has its messenger" (Q. 10:47), a messenger who can speak their language (Q. 14:4) and who will inaugurate the right way and open road (Q. 5:58) among them. Although the Islamic God is monotheistic, the Qur'an stays true to its inclusive principle by declaring: "You shall have your religion and I shall have my religion" (Q. 112:6). It is safe to say, therefore, that a fair community is inclusive of diversity, respectful of women, and a practitioner of non-violence. Modeling the Prophet's incorporation of existing social values, it is clear that developing a principle of wasatīyah does not always connote the mean between two extremes. In fact, its ethical framework could reflect the point of convergence among best practices, as exemplified by the Prophet.

Muslims take Muhammad's life-example seriously, for he provides a model of an ethical formation revolving around God's mercy. For them, being an ethical subject individually and communally in contemporary societies includes God's immanent presence. They refer to the Qur'an to define their faith and devotion to God. As having faith (imān) in God is an abstract matter, all Muslims, regardless of their worldviews and personal leanings, define it according to what is important for them. Broadly defined, the emphasis on having faith could be either ethical or political, for faith as an ethical framework allows the dissemination of proper conduct, whereas embracing it as a political ideology permits radicals to use it as a tool for propaganda and exclusion. Unfortunately, Muslims often find it difficult to separate faith's ethical emphasis and its political misuse because faith pertains to the Unseen (al-ghayb) (Q. 2:3). Since God is unseen any behavior done in God's name, even when it clearly violates Islam's mission as the mercy to the world (e.g., such as violence committed in its name) is covertly and sometimes overtly supported by some Muslims.

Women are particularly vulnerable to domestic and religious violence due to male Muslims' misuse of the Qur'an and Hadith. The masculine use of faith as a tool for implementing oppressive ideologies and practices violates the ethics of moderation. Qur'an 3:179 suggests that having faith in God means to discern good from evil and to measure how a specific action or ruling will impact the community. In other words, Muslim responses to having faith lies in doing good for humanity and treating one another in a good manner. Therefore, defining faith in terms of moral perfection on the individual and communal levels provides a foundational paradigm upon which the ethics of wasatiyah can be based. After all, this ethics encourages Muslims to embody their faith by witnessing God's mercy and fulfilling the prophetic mission of promoting a just community in all areas of life. 
Becoming a witness to God is a daily existential choice that attests to what the Prophet exemplified. Such a choice is voluntary, for having faith provides a common framework for how to live an Islamic life. The Qur'an defines God as One or through tawhìd in His Being (dhāt), attributes (sifât), and works $\left(a f^{\prime} \bar{a} l\right.$ ). The tawhidic paradigm promotes neither a plurality of deities nor persons in Godhead, but One God, the Most Beneficent, the Most Merciful (Q. $2: 163)$. In terms of His attributes, this reiterates the fact that all divine attributes belong only to God. His divinity cannot be found in human beings because "He is Allah, the One and Only; Allah, the Eternal, Absolute; He begetteh not, nor is He begetton; and there is none like unto Him" (Q. 112:1-4). Since God is unlike and dissimilar (tanzīh) to human beings, He is above language, gender constructs, patriarchy, paternalism, sexism, and any other human ways of knowing. In addition, He cannot be constructed in any way to support male superiority because Islam's ethical framework confers upon both men and women equal status and roles before God in terms of both genders as His vicegerent (khalïfah) and servant ('abd).

The ethics of wasatiyah grants men and women the status of ethical agents. The concept of human agency and equality is rooted in the ontological paradigm of God's existence as the ultimate source of humanity's origin and human beings' role in the world. God necessarily exists by virtue of Himself, independent of the world. The relationship between God and human beings is based on the pattern of the Creator and the created, and human existence starts with creation. The Qur'an speaks of humanity's origin in terms of material and immaterial substances. In material terms, this sequential process starts from dust (turāb), a semen drop (nutfah), and a clinging substance ('alaqah) that develops into an embryo (mudghah) for an appointed period (Q. 22:5). Even Adam and Jesus were created from dust (Q. 3:59). Some children live to a ripe old age (Q. 40:67); others do not. The Qur'an also mentions the source of the immaterial substance - the single person that resulted in humanity (nafs wähidah) from which the multiplicity of men and women originated and to the spirit (rüh) as the driving force of life (Q. 4:1). This equality in human origin and the creative process demonstrates that human existence consists of flesh and spirit and comprises an inclusive humanity that contains both men and women.

Promoting a just community falls within the legal framework as well. The Qur'an calls for equal duties and responsibilities in everyday life. In fact, its legal framework provides a complete way of life for Muslims to follow, one that confirms what has been revealed to the People of the Book (Ahl al-Kitäb) in the way of kitāb (the revelatory process) and hikmah (wisdom) (Q. 3:81). ${ }^{19}$ 
The term People of the Book is primarily reserved for religious communities that have received divinely revealed holy books. Embodying a scriptural prescription is therefore reserved for its followers. By extension, the Islamic legal system is applicable only to Muslims, both individually and communally. The Prophet showed that all citizens were included at the state level. Only the generated fiqh (legal discipline) discourses value people differently in terms of men, women, and dhimmīs (non-Muslims living in Islamic territories). If Muslims stay true to the prophetic example, establishing a just community demands inclusion. This standpoint requires Muslims to inhabit the embodiment of God's revelation through the intersection of law, knowledge, and justice within the contexts of individual devotion and a wider communal connection in a pluralistic society.

The intersection between kitāb and hikmah enables Muslims to have a spiritual relationship with God, the middle path between what is literal and what is hidden. The Prophet's night journey from Makkah to Jerusalem and later to the seventh heaven provides a religious foundation for mystical and spiritual experience. The Qur'an's descent from God and the Prophet's experience demonstrate the human ability to connect to a sphere beyond the five senses. Al-Ghazali (d. 1111) speaks about the prophetic faculty that allows people like the Prophet to gain knowledge intuitively. ${ }^{20}$ Both prophetic and spiritual journeys to God provide a model that Muslims - both men and women - can use to develop a personal relationship with God. In fact, Khadijah shows that one's spiritual connection to God has nothing to do with gender, for all that matters is the individual's virtue and deeds. The emphasis on one's ethical formation and its correlation to community making is the gist of the ethics of wasatizyah. Such an ethics is geared toward including virtuous men and women during the process of erecting a fair and inclusive community.

\section{Engaging Women in an Inclusive Community}

The concept of wasatiyah as ethical framework suggests perfection in terms of how every Muslim relates to God and to each other in creating a fair community. Even though women are one of the components of human relationships in any community, they are often treated as secondary. Muslim communities are known for their inability to treat women fairly. The 2014 World Economic Forum on gender gap indicates that most Muslim-majority countries have the widest gap when it comes to female advancement in health, education, politics, and economics. ${ }^{21}$ Addressing this gap is a daunting task, despite the fact that local governments, progressive religious leaders and 
scholars, and female activists are leading various gender egalitarian movements that look to Islam as a source for women's advancement and agency. The interplay of wasatizyah ethics is crucial in addressing this gender gap, for such efforts both advance women as ethical agents and promote their causes locally. Here, the term al-wasat (the middle ground) can be understood as the intersecting relationship between men and women in terms of embodying fairness and becoming a witness to all of the created (shuhadā' 'ala jamí' alkhalīq $\bar{a} t) .{ }^{22}$ To this end, I will show how including women in community making echoes the Islamic ethics of moderation and the value of women as ethical agents.

Attempts to transform this gender gap vary according to each society's social, political, cultural, and religious localities. Central to the debate is the Qur'an's role in either supporting or suppressing women's rights to equality. I propose to enter the debate by highlighting Islam's liberatory intent to value men and women as human equals and ethical agents. I demonstrate how the Qur'an was revealed to liberate both men and women by bestowing upon them the freedom to submit to God. Although the Qur'an promotes the inclusion of women by liberating them from the imposition of masculine values, virtues, and practices, as well as by acknowledging them as equal to men before God, the exclusive readings of the sacred text by male scholars and jurists produce a contradictory claim of gender: The different treatment of women is based upon biological determinism. However, women and egalitarian-minded scholars do find support for gender equality in the Qur'an. Bringing the intersecting role (wasat) of God's intent for human equality and the elimination of oppression into everyday life is the responsibility of both men and women.

Muslims inherit the responsibility to work for a fair and inclusive community from the Prophet, for the first revelation reminds them of his special status, importance, and responsibility to humanity. His character, both before and after receiving the revelation, is commendable. Tariq Ramadan describes his life as "a reflection of education from God in which God's messenger acted, reacted, and expressed himself about human beings and events in the name of his faith, in the lights of his morals." ${ }^{23}$ Every detail of his life from childhood to death provides a lesson from God about how to live a meaningful life according to the Educator's guidance. God's name al-Rabb (the Lord) connotes God's role as the educator and nurturer of all the material and immaterial worlds.

The revelation bestows the beginning of divine knowledge, and a moderate response to it, is expected. The Prophet received his revelation during Ramadan 
in his fortieth year. When Gabriel asked him to recite twice and the Prophet replied that he was not a reciter, the angel held him tightly for the third time and said ${ }^{24}$ : "Recite in the name of thy Sustainer who has created, created human out of germ-cell. Recite for thy Lord is the most bountiful, He who has taught by the pen, taught human what he knew not" (Q. 96:1-5).

What happened next is rather interesting. The Prophet went home with his heart beating heavily; his wife Khadijah consoled him. After he told her that "I fear that something may happen to me," Khadijah asserted that "Never! By Allah, Allah will never disgrace you. You keep good relations with your kith and kin, you are honest and help the poor the destitute, you serve your guests generously and assist the indigent calamity afflicted ones." ${ }^{25} \mathrm{Her}$ inclusion in this account reveals that divine knowledge affects both men and women equally. Khadijah's words and actions provide a model for Islam's epistemic formation as a moderate religion.

Khadijah also connected her husband's experience with the larger framework of prophecy in religious communities. The Prophet was bewildered by his encounter with Gabriel, who told him that "thou art the Apostle of God." ${ }^{26}$ Khadijah assured him, "Rejoice, O son of my uncle, and be of good heart. Verily by Him in whose hand is Khadija's soul, I have hope that thou wilt be the prophet of this people." ${ }^{27}$ Her wish was confirmed by her Christian cousin Waraqah ibn Nawfal, who told her, "Holy! Holy! Verily by Him in whose hand is Waraqa's soul, if thou hast spoken to me the truth, O Khadija, there hath come unto him the greatest Nāmūs (Gabriel) who came to Moses aforetime, and lo, he is the prophet of this people." 28 When Waraqah eventually met the Prophet as he was performing the ritual circumambulation of the Ka'bah, he asked Muhammad to recount the entire incident. He then corroborated it by saying, "Surely by Him in whose hand is Waraqa's soul, thou art the Prophet of this people. There hath come unto thee the greatest Nāmūs who came unto Moses. Thou wilt be called a liar, and they will use thee despitefully and cast thee out and fight against thee. Verily if I live to see that day, I will help God in such wise as $\mathrm{He}$ Knoweth." ${ }^{29}$ Here, Khadijah's decision to ask her Christian cousin reaffirmed her role as one of the original makers of Islam in its early community formation and signaled the inclusion of women's experience in Muslim society.

Khadijah provides an interpretive language for how to understand the Prophet's experience. Interestingly, she recalled the Judeo-Christian concept of prophecy to validate the first revelation. Her fascination with her husband's prophetic signs went back to Maysarah's story. Prior to her marriage, Khadi- 
jah had hired Muhammad to trade on her behalf in Syria and assigned her slave Maysarah to accompany him. Upon their return, Maysarah told her of the two angels who had shaded Muhammad and how "[t]he apostle stopped in the shade of a tree near a monk's cell, when the monk came up to Maysarah and asked about the Prophet Muhammad who happened to rest beneath the three. He told him that he was of Quraysh, the people who held sanctuary; and the monk exclaimed: 'None but a prophet ever sat beneath this tree."'30 Upon hearing the story, Waraqah remarked, "If this is true, Khadijah, verily Muhammad is the prophet of this people. I knew that a prophet of this people was to be expected."

Khadijah's familiarity with Christianity and her use of it to describe her husband's prophetic experience resonates with al-Wahidi's account that Muhammad used to listen to Christian slaves reciting their scriptures when he passed by them. ${ }^{31}$ Clearly, both of them had some degree of familiarity with Christianity. Waraqah contributed to how the Prophet approached the revelation. When the Prophet informed him that he used to hear someone calling him "O Muhammad!" he would run away and ignore it; Waraqah advised him to stay and listen to it. This suggestion was partly important because it related to the revelation of the Opening Chapter. ${ }^{32}$ Khadija's familiarity with Christianity reiterates Reza Aslan's point about Judaism and Christianity's influential presence in Makkah.

The Prophet took a moderate stand on women's issues after the revelation began. The Qur'an's gradual descent introduces a new sense of equality between men and women, one that serves as a meeting point at which rights, duties, and responsibilities are defined for both genders in a just and complementary manner. Islam defines gender equality in terms of moral growth and each person's potential for engaging in good works. Such equality acknowledges that men and women are endowed with abilities for ethical deliberation and choice, a fact that is made clear in Q. 33:35, as follows:

Indeed, the Muslim men and Muslim women, the believing men and believing women, the obedient men and obedient women, the truthful men and truthful women, the patient men and patient women, the humble men and humble women, the charitable men and charitable women, the fasting men and fasting women, the men who guard their private parts and the women who do so, and the men who remember Allah often and the women who do so - for them Allah has prepared forgiveness and a great reward.

The above verse expects men and women to be on their best behavior and support each other, so that they can achieve perfection in their lives. By ex- 
pecting them to endow themselves with virtuous characteristics, both genders are equally prepared to become functional members of any fair community. Here, individual piety and voluntary participation is the foundation of community making.

Efforts to habituate virtuous characters take into consideration each Muslim's understanding of the Qur'an. As a textual evidence of God's divine message, this text shapes Muslims; however, at the same time Muslims shape its interpretations. For the most part, the dynamics of the Qur'anic interpretation serve as the ethical paradigm that governs each person's relationship with God, fellow human beings, and nature. Muslims cite it for almost everything either by quoting its verses literally or interpreting them symbolically and contextually. At the heart of this practice is the individual Muslim's attempt in his/her innermost self to forge a meaningful relationship with God either by extrapolating upon what is said and not said in the Qur'an or by appropriating its verses in legalistic, mystical, and theological terms. In general, Muslim men decide, produce, and reproduce what is normative and prescriptive, whereas women receive these male-determined social norms and do their best to conform to them. This different access to the Qur'an causes the gender gap. In response, a new wave of interpretation by Muslim women is geared toward a more egalitarian interpretation and produces an epistemological foundation of Qur'anic support for gender equality.

The Qur'an's utility as a reference for promoting gender equality and addressing the social, political, cultural, economic, and familial institutionalizations of the gender gap plays a crucial role in advocating Muslim women's causes. Such efforts are very necessary, given that promoting a more equitable relationship is framed within the western paradigm of feminism, democracy, gender equality, and human rights. Since this approach, when used in the Muslim world, sometimes presumes Muslim women's oppression to be the fault of Islam, their inward-looking worldview of Islam serves as the underlying foundation for piety, justice, and equality. Oppression certainly exists, but it is in no way unique to Muslim women. ${ }^{33}$ Their subordinate position has nothing to do with religion, but rather with the excessive amount of economic, politically, and socially dominant structures controlled by men. The ethics of wasatityah here is to be understood as the convergence of education and opportunity to exercise choice in public; otherwise, educated women will have nothing to contribute to erecting a fair and inclusive community.

Such a community can be achieved only with women's greater education and participation, for denying them a greater public role will result in their continued subjection to the existing status quo that defines gender roles and 
rights in terms of male experience. As the masculine construct of gender issues reflects the time, condition, and attitude of local politics, along with those of the cultures and societies in question, such barriers challenge the promotion of gender equality. The Islamic paradigm of gender equality, due to in ontological origin, ethical role, and eschatological reward, often faces a harsh reality, one in which misogyny and sexism influence how the Qur'an is understood and how cultural and social practices are enforced. The existing gap between the Qur'anic virtue of equality and the misogynist interpretation, not to mention the sexist treatment of women, seems paradoxical. I highlight the paradox between gender egalitarianism and hierarchy, compassion and marital violence, and economic dependence and independence.

Promoting the egalitarian view of gender roles and rules seems to contradict the hierarchical view of how women are expected to conduct themselves both socially and culturally. Gender egalitarianism promotes all people's inherent equality before God regardless of sex, class, and gender difference, whereas gender hierarchy claims that the natural difference between men and women entails ontological, social, political, and financial differences. ${ }^{34}$ Gender hierarchy is more prevalent in the social imaginary than the virtue of gender equality. The common assumption about gender issues relies on the male superiority in terms of origin, family, economics, and politics. Such an assumption has its foundation in the prevalent literal reading of the Qur' an, which generates both the portrayal of men as God's substitute and of women as inferior beings.

Below are some examples of the assumptions that shape the social imaginary and the public truth of male superiority and female inferiority.

- Men's superiority arises from their biological origin as the primary creation, whereas that of females is secondary.

- Biological or sexual difference justifies male superiority in perpetuating humanity because men are valued as the moving principle of conception.

- Biological and sexual distinctions justify the familial division of labor. Men are held to be superior because the Qur'an privileges them in economics, inheritance, divorce, and the right to beat their wives and act as witnesses.

- It is natural for husbands, as the breadwinners, to be in charge of the family's social standing and its members' morality; wives are limited to taking care of the household and couple's children.

- The sexual division of labor divides private from public, personal from political, appropriate from inappropriate, obedience from disobedience, 
virtue from vice, dignity from humility, and other categories that perpetuate the status quo of the hierarchical gender system.

- Men and women, therefore, are not equal in every respect.

This scriptural reading of the Qur' an as favoring men reveals how gender inequality is prevalent in Muslim consciousness and practices.

Efforts by female Muslim scholars to dispel the source of inequality in Islam vary. Historian Leila Ahmed points to Islam's assimilation of existing patriarchal cultures as it took root in the Arabian Peninsula and spread outward..$^{35}$ The Qur'an was revealed in a society where men dominated both private and public life. Allan G. Johnson defines patriarchy broadly as not only "male-dominated, male-identified, and male-centered character," but also a "set of symbols and ideas that make up a culture embodied by everything from the content of everyday conversation to literature and film." ${ }^{36}$ Islam certainly did not invent this system there; rather, it existed prior to Islam and was common worldwide. ${ }^{37}$ In fact, the Qur'an records the societal reaction to the birth of a girl: "[W]hen news is brought to one of them of (the birth of) a female (child), his face darkens, and he is filled with inward grief!" (Q. 16:58).

These sexist cultures provide the contexts in which gender inequality can persist within Muslim-majority societies. The subordinate treatment of women was exacerbated as the Arabs conquered the Byzantine and Sasanian empires, for the "conceptions, assumptions, and social customs and institutions relating to women and to the social meaning that derived from the traditions in the Middle East at the time of the Islamic conquests entered into and helped to shape the very foundations of Islamic concept and social practice as they developed during the first centuries of Islam." ${ }^{38}$ Muslims' treatment of women is, therefore, culturally specific and depends upon the historical memory and contextual challenges.

The assimilation of neighboring cultures as well as those that Islam encountered during its formative period, as well as the continued mixture between Islamic civilization and the earlier civilizations, shaped how the Qur'an was understood and interpreted. The theological, social, and legal interpretations of the Qur'an all favor men over women. This dominance in understanding what it reveals about God and the prophets produces the imaginary of "the Father/fathers." Asma Barlas argues that such an imaginary is improper because the Qur'an does not allow us to perceive God as father/male or promote "theories of father-right/rule and male privilege." 39 The imposition of male privilege directly violates the ethics of wasativyah, in which men and women 
are valued equally as ethical agents whose service and contribution to community making is valued.

A literal reading validates the subordination of women. Muslim women continue to state that several verses are read with a masculine tone and preference: inheritance (Q. 4:11, 176), testimony (Q. 2:282), divorce (Q. 2:228), interfaith marriage (Q. 2:221), and a harsher punishment for fornication (Q. 24:2). Men have a superior position in both private and public spheres due to their roles as leaders or caretakers (qawwämah) of women. It follows, therefore, that any violation of male leadership and control, not to mention a woman's disobedience, could be punishable by beating (Q. 4:34). Better yet, only men can be polygamous (Q. 4:3). Some Muslim women are challenging these literal interpretations in order to address the resulting impact on their lives by offering a contextual interpretation as a way to promote gender equality and fight discrimination based upon religious ideology.

The concept of wasativyah as an ethical framework enhances women's pursuit of gender equality and addresses oppressive practices. Such efforts will impact Muslims both individually and socially. As Muslims are involved in community building, they must serve as witnesses to God's vision and guidance to the straight path and His mercy to humanity. ${ }^{40}$ At the individual and communal levels, this means demonstrating fairness ( ' $a d l$ ), benefiting humanity, promoting the right and forbidding the wrong, and having faith in God in the ethical sense (Q. 3:110).

To create a fair and just community, Muslims are responsible for promoting the ethics of moderation in all affairs and avoiding all extreme or viceladen behaviors in religious and worldly matters. With this in mind, we cannot afford to frame wasat in terms of moderation between the Jews' religious exaggeration and the Christians' religious reductionism in order to demonstrate Islam's perfect example of a fair and just community. ${ }^{41}$ The term wasat implies that men and women ought to be moderate in their behavior, choice, character, and religious devotion. With this in mind, the making of a fair and inclusive community requires the habituation of virtue, piety, and service by all members of society.

\section{Conclusion}

The principle of wasatizyah as an ethical framework provides a common paradigm that all Muslims can use to embody God's message and lead a meaningful life. The Qur' an bases its premise on gender equality as regards all human beings' common origin, biological constitution, and return to God. 
Certainly class, gender, patriarchy, and social status often determine how human equality is perceived. The Qur'an does not deny the interplay of social constructions that often interfere with human interactions. However, it does appeal to all human beings to do their best to establish God's order, knowledge, and wisdom and to display them in their daily lives. The order that God introduced through revelation relies on the convergence of human excellence and divine revelation. Thus an ethics of wasativyah not only deals with the formation of a moderate individual endowed with a virtuous character who can project his/her excellence on society, but also allows for the creation of a fair and moderate community.

The wasatîyah ethics in community building affords Muslim women the opportunity to become witnesses to humanity (shuhadā' 'ala al-nās) and what it means to be Muslim in a meaningful way. Becoming a witness for Islam means that Muslim men and women must embody Islamic values and virtues in a moderate manner. As witnesses, Muslim women demand that they be allowed to carry out this duty through their pious and virtuous behavior, activism for justice, civic engagement, and public service. When they lead by valuable and meaningful examples, their good behavior becomes visible..$^{42}$ At the same time, the ethics of wasatīyah oppose any political behavior and action that, in the name of Islam, yields to violence and destruction, for they cannot be considered acts of witnessing to humanity. This type of ethics is, therefore, about witnessing to Islam's message through good character in multiple settings. Efforts to formulate and then apply these ethics require more research.

\section{Endnotes}

1. Mohd Shukri Hanapi, "The Wasatiyyah (Moderation) Concept in Islamic Epistemology: A Case Study of Its Implementation in Malaysia," International Journal of Humanities and Social Science 4, no. 9(1) (July 2014): 51-62.

2. Raymond William Baker, "Worldly Islam: The Islamic Wasatiyyah and the Quest for Democracy," Oriente Moderno 87, no. 2 (new series) (2007): 353.

3. Mohammad Hashim Kamali, "Islamic Family Law Reform," International Institute of Advanced Islamic Studies Malaysia 3, no. 1 (2011): 52

4. Hanapi, "The Wasatiyyah (Moderation) Concept in Islamic Epistemology," 5162; Baker, "Worldly Islam," 327-54; and Kamali, "Islamic Family Law Reform," 37-52.

5. Daniel H. Frank, "Ethics," in History of Islamic Philosophy, ed. Seyyed Hossein Nasr and Oliver Leaman, part 2 (London and New York: Routledge, 1996), 95978. 
6. Yusuf Ali's translation: "Thus, have We made of you an Ummat justly balanced, that ye might be witnesses over the nations, and the Messenger a witness over yourselves; and We appointed the Qibla to which thou wast used, only to test those who followed the Messenger from those who would turn on their heels (From the Faith). Indeed it was (A change) momentous, except to those guided by Allah. And never would Allah Make your faith of no effect. For Allah is to all people Most surely full of kindness, Most Merciful."

7. Ibn al-'Arabi, Ahkām al-Qur'ān, ed. 'Ali Muhammad al-Bajawi (Cairo: Dar alFikr, 1967), 40.

8. Al-Mawardi, Al-Nukat wa al- 'Uyūn: Tafsìr al-Māward̄̄ (Beirut: Dar al-Kutub al-'Ilmiyyah, n.d.), 1:198-99.

9. Hanapi, "The Wasatiyyah (Moderation) Concept in Islamic Epistemology," 54.

10. Abu al-Hassan Ali ibn Ahmad al-Wahidi al-Naisaburi, Reasons of Revelation of the Glorious Qur'an, trans. Z. Baintner (Karachi: Darul Ishaat, 2005), 73-74.

11. Omid Safi, Memories of Muhammad: Why the Prophet Matters (New York: HarperOne, 2009), 98-100.

12. Toshihiko Izutsu, God and Man in the Qur'an (Kuala Lumpur: Islamic Book Trust, 2002), 104-05.

13. Reza Aslan, No god but God: The Origin, Evolution, and Future of Islam (New York: Random House, 2005), 8.

14. Ibid., 10.

15. Tariq Ramadan, In the Footsteps of the Prophet: Lessons from the Life of Muhammad (New York: Oxford University Press, 2007), 19 and 30.

16. Sachiko Murata and William C. Chittick, The Vision of Islam (St. Paul: Paragon House, 1994), xx.

17. See the translation by Mohsin Khan on http://corpus.quran.com/translation.jsp ?chapter $=6 \&$ verse $=161$ (accessed on May 15, 2013).

18. See Murata and Chittick's discussion on God in The Vision of Islam, 47.

19. Daniel Madigan, The Qur'an's Self-Image: Writing and Authority in Islam's Scripture (Princeton: Princeton University Press, 2001).

20. Al-Ghazzali, The Faith and Practice of Al-Ghazálí, ed. Wiliam Montgomery Watt (Oxford: Oneworld, 2000).

21. http://www.weforum.org/reports/global-gender-gap-report-2014 (accessed, January 11, 2015).

22. Ibn al-'Arabi, Ahkām al-Qur'ān, 40.

23. Ramadan, In the Footsteps of the Prophet, xi.

24. Martin Lings, Muhammad: His Life Based on the Earliest Sources (Rochester, VT: Inner Traditions International, 1983), 43-44.

25. Al-Naisaburi, Reasons of Revelation of the Glorious Qur'an, 47.

26. Ibn Ishaq, The Life of Muhammad: A Translation of Ishāqu's Sìrat Muhammad (Karachi: Oxford: Oxford University Press, 1967), 106.

27. Ibid., 107.

28. Ibid. 
29. Ibid., 107.

30. Ibid., 82-83.

31. Al-Naisaburi, Reasons of Revelation of the Glorious Qur'an, 279.

32. Ibid., p. 53.

33. Chandra Talpade Mohanty, "Under Western Eyes: Feminist Scholarship and Colonial Discourses," in Third World Women and the Politics of Feminism, ed. Chandra Talpade Mohanty, Ann Russo, and Lourdes Torres (Bloomington and Indianapolis: Indiana University Press, 1991), 51-80.

34. Etin Anwar, Gender and Self in Islam (New York: Routledge, 2006), 19-21.

35. Leila Ahmed, Women and Gender in Islam: Historical Roots of a Modern Debate (New Haven: Yale University Press, 1992).

36. Allan G. Johnson, "Patriarchy, the System: An It, Not a He, a Them, or an Us," in Women's Lives: Multicultural Perspectives, ed. Gwyn Kirk and Margo Okazawa-Rey (New York: McGraw Hill, 2000), 29-30.

37. Estelle B. Freedman, No Turning Back: The History of Feminism and the Future of Women (New York : Ballantine Books, 2002). See also Ahmed, Women and Gender in Islam, 4-5 and 13-14.

38. Ibid., 5 .

39. Asma Barlas, "Believing Women” in Islam: Unreading Patriarchal Interpretations of the Qur'an (Austin: University of Texas Press, 2002), 127.

40. Wahbah al-Zahili, Al-Tafsīr al-Munī fi al- 'Aqīdah wa al-Sharī' ah wa al-Manhaj, vols. 1-2 (Damascus, Dar al-Fikr, 2003), 369.

41. Ibid., 369.

42. Al-Qasimi, Tafsīr al-Qāsimī (Maḥāsin al-Ta'wīl) (Beirut: Dar al-Kutub al'Ilmiyyah, 2003), 1:414. 